\title{
A Walk in the Forest
}

\author{
By RAY PETERSON, R.R. 2, Tofield, Alberta
}

In late November while at Foothills, Alberta, which, as the name suggests, is close to the Rockies, I enjoyed a leisurely hike. Exceptionally mild weather and a remarkable absence of snow enhanced the outing.

Leaving the camp on one of the many logging trails that fanned out from it, I was soon engrossed in comparing the semi-mountainous region to the farm back home. Even a casual eye can see striking evidence of how Nature adapts herself to different terrains.

The bulldozed road swung along a ridge of slim, clean-boled lodgepole pine that reached up into the sky like flag poles decked in green bunting. A squirrel eyed me brightly from an old stump, scolded briefly, then resumed twisting a pine cone between deft paws as he nibbled at the seeds. With a raucous voice that belied his quaker suit, a whisky jack followed me for a short distance. Prize panr. handler of the bush, he seemed to be hoping that I would stop to have lunch.

The trail dipped through a belt of spruce and balsam fir, and entered a muskeg dotted with tamarack and clumps of oddly twisted black spruce.

I left the trail, there, and crossed to a small, pine-covered hill. Moss, four inches thick in spots, spread a luxuriant carpet through the trees. Enthroned on little mounds of green were necklaces of frost-sweetened cranberries. I gathered some of the fruit and crimson stained fingers and mouth attested to my. greediness. Here too, were a few bunchberries, still well preserved, and further on surprisingly fresh-appearing mushrooms. Small, cream colored plants, they had. a sweet, very pleasing taste.

From a clump of alders a flock of chickadees dee-ed for attention. The brownish markings on their fluffy bodies labelled them as Brown-headed chickadees, back-wood cousins of the common, black-capped chickadee. Closeby, that trip-hammer artist, 'a Downy woodpecker billed a resounding din from an old pine rampike. A raven passed overhead, his melancholy voice sounding like a crow with a bad cold. In contrast came the soft, muted whistlings of a flock of colorful pine grosbeaks.

Nearing camp, I followed a little stream that was nolsily adding its song to the rushing voice of the nearby Pembina River. A plump, grey bird flickered suddenly into view. Wading sturdlly in the sweep of the ice-lined brook, it plunged head and shoulders into the water. Then, uttering an odd note that seemed to blend with the cry of the water, it darted over the wet rocks of the stream, and flipped up to perch upon an overhanging windfall. Never still an instant, its body teetered, up down, up down, turning in an erratic circle at the same time untll one would think that the bird would surely make itself dizzy and fall back into the water. It was my first sight of a Water-ouzel, or Dipper, and I watched it lascinated for quite a few minutes. Eventually, however, its strange anties in the icy water made me shiver and I moved on.

Mingled with the scent of spruce and pine came the clean tang of woodsmoke. A late sun glimmered redly through the evergreens and touched the roofs of the camp. My hike was over.

\section{Executive Meeting}

The first executive meeting of the Society for the year was held in Regina on January 26. Among many topics of importance which were discussed was the desirability of joining with the Alberta and Manitoba Natural History Societies. At the annual meeting a resolution dealing with this problem was set aside pending further consideration and discussion by the executive.

We decided to postpone action on this question for the present because we have been fairly successful in getting the Blue Jay into Saskatchewan schools, and because administration, even at this level of our development, has not been solved.

The executive meeting did suggest, however, that certain pages of the Blue Jay be set aside for the use of (Continued on Page 12) 